Karel PioreckÝ, Vojtěch MalíneK

Akademie věd České republiky

\title{
Czech Literary Culture in the Post-Digital Era ${ }^{1}$
}

The first decade of the new millennium has not started with a revolutionary turn for the Czech society and literature like the decade before. Thus, the year 2000 (or 2001) is not such a milestone-it does not mean the end or the beginning of anything within Czech literature. Nevertheless, the first years of the new millennium did represent a change within Czech literature, which can be compared to the post-Velvet Revolution transformation of Czech literature. This change was not revolutionary but rather evolutionary; it was less striking, and for that reason perhaps more significant. An important (although not the only) aspect of this change was the gradual increase in the use of the Internet in public communication and the subsequent restructuring of discourse within the media, including literary discourse. Since the digital revolution of the turn of the 1990s, literary culture has subsumed the principles of the so-called post-digital culture,

1 This study was written as a result of "Czech Literary Bibliography-Czech Literary Internet: data, analyses, research" project implementation (Nr. CZ.02.1.01/o.o/o.o/16 013/ooo1743), which is financed by the European Union through European Structural and Investment Funds within the Research, Development and Education Operational Programme.

This work required the use of Czech Literary Bibliography research infrastructure resources (http://clb.ucl.cas.cz). 
where digital media are no longer treated as something novel and curious but as an everyday "humanised" part of this culture (Cramer 2014). Which areas of literature does this remediation process affect and how is it reflected in those areas? Which other processes have changed Czech literature since the beginning of the millennium? Are there similarities or differences between the way Czech literature evolved compared to other neighbouring Central European cultures? These are the key questions posed by this study, which mainly concern the basic aspects of the literary system, and thus this study refers to one of the theoretical systemic literary models-a model proposed by Siegfried J. Schmidt. This is a model that has paid attention to the mediated nature of the literary process and the change of media discourse and is the main initiator of the investigated changes. The term literary system used here essentially means "social literary system" proposed by Siegfried J. Schmidt to label a systemic structure formed by four roles of action: production, mediation, reception and processing phenomena regarded as literary (Schmidt 2008). The interpretation that follows is structured according to these roles of action.

\section{Production}

Production (if understood in a narrow sense as a genesis of literary texts) is a component of the literary system, which was marginally affected by the examined changes within Czech literature. This is the first feature unique to Czech literary culture in the post-digital era, as other Central European literatures have undergone transformations, be it partial, even in production, thanks to some literary figures or groups working in the field of electronic literature (e-lit). Slovak literature has contributed significantly to developing the genre of digital poetry thanks to the work of Zuzana Husárová. Electronic literature in Poland has developed to an even greater extent thanks to writers (such as Romana Brombosz, Sławomir Shuty, Leszek Onak and Łukasz Podgórni) or groups (such as Perfokarta and Rozdzielczość Chleba). Austrian literature has some excellent examples, such as Jörg Piringer; and there are examples of hypertexts written by Hungarian authors, such as Péter Farkas.

As far as the writing technology is concerned, the post millennium period does not differ much from the preceding period-the shift from manual or type-writer writing to text-editor assisted writing has occurred in the preceding decade. However, the fact that, in the new millennium, computers stop being "better type-writers" and become boundaries of network-shared data and interactions even in the writers' offices, did have an impact on the genesis of literary texts. The Internet has created relatively high expectations among 
literary publicists, not primarily among writers. In 2001, Czech literary journals have carried out several questionnaires among writers, asking them about their views on the Internet and what prospects this medium held for contemporary literature. The topic of "Internet literature" was in the air, and it was coming from abroad. The questionnaires nevertheless showed that the majority of the surveyed writers were largely unaware of this trend. When asked by Literární noviny monthly, "What do you think of the Internet literature?", Daniela Hodrová answered saying "I am not familiar with the Internet literature; not that I am avoiding it but I do not have the Internet at home and do not intend to get it." The only one who found this question a bit easier was Ondřej Neff, an Internet enthusiast and editor of an electronic paper entitled Neviditelný pes (The Invisible Dog). He said that he: "discovered an intimate human space instead of something technically cold ... I find a continuous stream of a kind of anonymous folk storytelling" (Hodrová et al. 2001: 10).

The current reception of the Internet ranged in views widely-between scepticism and fear around the fading interest in books and reading to enthusiastic visionary perspectives of the future, new literary world. The Internet has not been utilised in the Czech context in terms of some of the genres of electronic literature (apart from a few attempts at the end of 1990s). The only area where there was a partial shift in production mechanisms was in popular literature where the net medium motivated authors to increase interactions with their reader communities and engage them in producing literary texts. This happened particularly within the genre of novel series, which was revitalised thanks to freely available online blogging utilities. Readers were engaged in the process of writing through questionnaires regarding their preferred development of the stories, through debates related to individual episodes of the novels or direct involvement in the emerging text where readers could create the following episodes. Michal Viewegh used the last form in his project Blogový román (Blog novel), which ran on the Internet pages of the Czech daily Mladá fronta Dnes (http://blogovyroman.idnes.cz/, accessed 10 April 2019) between August and December 2009 and Viewegh invited the readers join him in writing a novel to be continued. He wrote the first chapter, outlined the nature of his characters and invited readers to join in writing the following chapters of the novel. This prose of ten chapters was written via competition where an established author shares the authorship with his readers. This way, Viewegh formed an illusion of eliminating the distance between the author and readers and created seeming intimacy (referring to his promise of personal emails to participants of the competition). This is a clear example of shifting boundaries between the author and reader, which were brought into literary communication by the Internet. 
This is also a clear example of the digital medium being used for marketing purposes (for the benefit of the commercial author, sponsor of the competition and newspaper website which published the Blog novel).

There were similar projects in other Central European countries, for instance Slovensko piše román (Slovakia Writes a Novel) project which took place between May and October 2009. It was edited by a commercially successful prose writer Evita Urbaníková, who wrote the introductory and final chapters and selected chapters sent in by readers, which eventually became part of the published novel. The competition was sponsored by an online book store Martinus.sk.

Such collective production activities were further instigated by social networks. The marketing aspect is fairly insignificant here, as this is a form of entertainment within communities interested in creative writing. Since December 2014, a Facebook group called Povídky ze zdi (společné tvưrčípsani) (Short Stories from the Wall (Collective Creative Writing)) has been operating, the aim of which is also a collective, resp. community creation of shorter narratives. Here the competitive aspect of collaborative writing is eliminated, and it is dominated by a community principle of collaboration and communication. Compared to similar Twitter projects, such as Twitteropsaní s Jaroslavem Rudišem (Twitter Writing with Jaroslav Rudiš) or Píšeme román (We are Writing a Novel) found on www.twitter.com/piseme_roman, setting a word limit does not play much of a role-writers are only advised that their piece be between one to three standard pages. The community's (group's) founder and administrator, Zuzana Dostálová, plays a key role. It is the group administrator who sets the topic and writes the introduction to each short story. The administrator also publishes weekly schedules with group member name for every day, and each day the given member publishes their section through the comment box. The next day a selected co-author adds their episode. The comment box thus holds a mixture of individual episodes and comments by other co-authors and readers or other group members. The text without comments is published in the Collection section. Despite its relatively short period of existence, the group is fairly large-on 15 March 2019, it had 777 members. What is also unique about this group is that unestablished authors take part in it alongside established writers and personalities from other fields of culture (journalist Renata Kalenská, Romanist Alena Scheinostová, prose writer Kateřina Tučková, radio editor Pavla Horáková, prose writer Bianca Bellová, poet Olga Stehlíková and others).

Apart from collective creative works, social networks bring other global literary trends into Czech literary culture. These are situated in between production and mediation and have a unique intermedia character. Instagram 
poetry (instapoetry) has become the phenomenon of the past few years-this is a form of amateur literary production which is a natural fit with social media. Compared to the contributions to amateur literary fora, with instapoetry, the text component plays only a partial role in the final form, as a distinct visual component-whether this is typography (with frequent imitations of type-writing or photographs of type-writing, e.g. receipt@type_written), a key connection between a drawing and text (e.g. Poem 29 cycle on a receipt mxre_cxtu) or spatial installation of text through a camera (e.g. on receipt poezievmestezije [poetryisaliveinthecity], where receipts with poems are photographed in Prague streets). Textual poetry production is de facto transformed into production of a painting distributed via a visually-focused social network, and the final form is a multimedia combination of textual and visual components, where the visual aspect frequently dominates disproportionately.

There is a smaller, however from an artistic and critical angle, more significant field of literary text production, where particularly the creation of a poem is automated using artificial networks of neurons. A rapid expansion of artificial intelligence (AI) brought automated generation of poems virtually to all developed literary cultures, including the Central European (the Czech culture is not an exception). A Czech example of successful use of AI is a project of an automated poet carried out by a programmer, maths linguist and former head of development department for the seznam.cz server, Jiří Materna. This approach to literary text production is unique through its significantly diminishing role of a human actor in the genesis of the text-a human plays more of a role of an operator and organiser of the creative process, but not a subject, as creation of a text of a poem is automated through statistical generation inside a network of neurons trained on a large corpus of poems. Materna trained his network of neurons using 80,000 poems drawn from an amateur literary forum Písmák.cz. His project resulted in a collection entitled Poezie umělého světa (Poetry of an Artificial World) (2016, can be downloaded for free at kosmas.cz; Materna 2016). The quality of these poems very closely resembles their online prototypes. Materna's collection not only documents the functionality of the applied algorithm but is also (inadvertent but compelling) critique of the standard of the poems published at Písmák: the poems are typically structured in primitive stanzas, fleeting reflections of current feelings, banality of thought or romantic confessions.

The factors which influenced the production of early millennial literary texts were given by the general characteristics of open online platforms: these are (a) unrestricted publishing space which motivates production of texts through openness and accessibility and (b) a radically democratised concept 
of authorship, where there are no barriers traditionally caused by actors operating between the production and mediation of texts (such as publisher, editor or proof-reader etc.). The fact that this change is paradigmatic and might be reflected not only in online production can be statistically proven using data showing an increase in literary production among Czech population. Czech literary bibliography data (https://clb.ucl.cas.cz/) show that literary active people share per population over the past twenty years has virtually increased by nearly $50 \%$. In the 1990s, the proportion of literary active individuals per 10,000 people was slightly above $10 \%$; over the past decade, the number increased to nearly $15 \%$ (see Figure 1 below). By "literary active" we mean individuals who published at least one text (an article, study or book) recorded in Czech literary bibliography in the past year with known biographic data, that means it is proven that given identity is not a pseudonym. ${ }^{2}$

\section{Proportion of literary active individuals per population of 10,000 in a year}

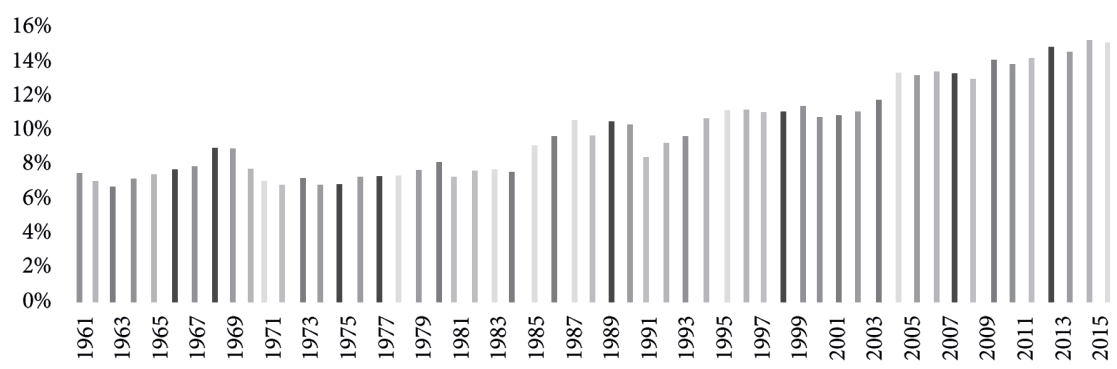

Figure 1

2 The input data originate from August 2018 and cover the 1961 to 2015 period, and were processed according to the uniform excerpting norm as secondary bibliography (excerpts record texts concerning Czech literature, not imprints of fiction-these are recorded only for currently processed bibliographies of Czech literary samizdat and Czech online literature). Due to changes in the scope of excerpts and limited available biographical data on the latest authors and potential related misrepresentation, data after $\mathbf{2 0 1 6}$ are not included. The data also roughly reflect only the part of the excerpted material for the ongoing Czech online literature project; when it is completed (2021), the data can be analysed in a greater detail. In general, a shift in absolute numbers not so much in trends can be anticipated. 
A similar increase is observed in absolute numbers. While in the 1990s, Czech literary bibliography recorded on average around 1100 individuals who published at least one article per year, after 2010 this increased to around 1600 (see Figure 2 below).

\section{Number of literary active per population (at least one publication recorded in Czech literary bibliography in current year)}

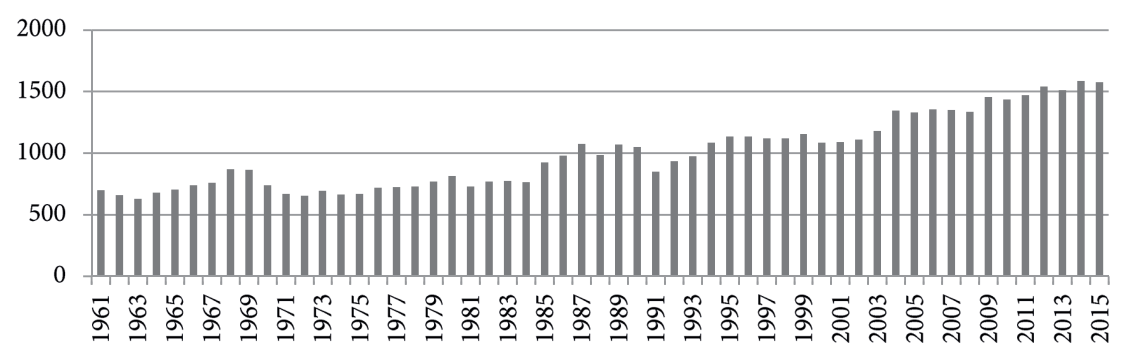

Figure 2

This change in the production paradigm clearly must have fairly significantly impacted on mediation of literature including the book market.

\section{Mediation}

Free, open publishing platforms available on the Internet: blogs and in the Czech context very popular literary fora (known slightly confusingly as "literary servers") brought a significant change in mediation of literary texts. Established and novice Czech writers started using these platforms already in the second half of the 1990s. The first literary server was launched in 1997; however, the boom in their use came in the first decade of the 2000 (thanks to the improvement in Internet accessibility even for households). After 2000, there were more than twenty websites of this kind (some of them still exist) available on the Czech Internet.

Písmák, launched in 1997, is one the oldest and most frequently used literary servers; in 1999, the literary server Totem was launched; and in the following years, many other servers appeared (e.g. LiTerra, Liter. 
cz, Blue World and Epika). The growth in interest in literary servers can be documented by the growth in visits of the www.pismak.cz website-in 2000, 400 people visited the site daily and then it has grown sharply to 2,800 per day in 2011 .

Publishing platforms of this kind have appeared and do appear globally, but there is a uniquely Czech aspect to this. It is the number of users and contributors. For instance, in January 2009, 35,675 users were registered on the Písmák forum, and according to the owner of the website, Roman Plojhar, 8,00o were active contributors (see Košinská, 2009: 26). In 2011, 2,800 users logged into the site daily. In 2009, the Totem forum had around 30,000 registered users and offered 265,00o contributions. The only other literary site which has more users than Czech literary fora is poetry.com website, which counts seven million users.

It is the numbers that distinguish the Czech literary fora as unique and atypical in an international context. For instance, the German literary forum Leselupe. de with 4,744 registered users presents itself as a large or one of the largest German literary fora. Its numbers are only a fraction of the user numbers for the Czech Písmák or Totem fora, and yet Leselupe users come from a significantly larger language population. Not even the Anglophone deepundergroundpoetry. com site with 16,071 registered users can match the numbers for the Czech literary fora. Even the number of contributions is significantly higher-in 2009, Totem had 265,000 contributions, while Leselupe had around 70,000 in the same year. What is interesting about the German site are the numbers who visit the site-the number of visits per month is around 150,000 (2009 data), which is around 5,000 visits a day, and this is significantly higher than the number of registered users in that year (around 4,00o). Písmák reached its peak in the number of visits in 2011 with 2,800 visits per day. Therefore, one of the differences between the Czech websites and Leselupe is possibly in the presence of readers ("lurkers") among the website users, who only read on the website. Such a group is almost non-existent on the Czech literary fora, certainly not in such numbers (it is 1,00o "pure" readers a day). This is possibly one of the unique features of the Czech literary fora. Another unique feature of the Czech literary internet is the language component of its content-there is not an insignificant number of contributions in the Slovak language, for the largest fora, the proportion of Slovak contributions is around $20 \%$ (21\% for Písmák, $16 \%$ for the second largest Totem forum). ${ }^{3}$ Thus, literary fora also mediate Czech-Slovak literary relations which develop a lot more broadly within

3 Data was collected for the Corpus of current poetry project. 
this open space than, e.g. in the traditional print media, journals and book production (where there is not as much space and Slovak texts also tend to be translated into Czech).

This type of media eliminates institutional actors from the mediation process and publishing becomes the matter of purely the author's personal choice. The author's role is strengthened in such a communication process and the imaginary line between production and mediation of literary texts becomes blurred (the author has control over his/her text even after it is published, can edit it, expand it or delete it later). The authorship itself has been transformed, radically democratised. Publishing is perceived as a right, not just as an opportunity. Such opinions are not confined within the space of online publishing but have expanded into the sphere of book culture.

Publishers based on the print on demand (POD) principle have developed direct links with open publishing platforms (literary fora). There is such a link between, e.g. Epika literary forum which is also a publisher holding the same name; or Liter.cz connected with the POD publisher Nová forma. Contributors to literary fora are economically advantaged in such cases compared to other clients (contributors receive discounts) or they are rewarded for publishing a book (e.g. get access to comments and assessment of contributions). These business projects are based on a premise that publishing a book and entering the sphere of print media is the aim and reward for the contributors to literary fora. Combining the POD publisher with a literary forum is aimed to secure a large enough customer base for publishing services. Knihovnička.cz is one of the most popular providers of such services, and towards the end of 20oos, Dokořán or Knihy pro radost also offered such services. In 2008, the A2 weekly stated that: "Thanks to the services offered by the PoDs, everybody has the opportunity to fulfil their writer's dream" (Růžička 2008: 26). It is therefore not difficult to guess what were the consequences of such radically democratic processes of mediating the book market, which were enabled by changes in mediation but also by pure economics. Book publishing has become technologically very easy. It is therefore no surprise that the numbers of published books coming on the Czech book market has grown year on year to such an extent that the amount of books has started to paralyse the market and it made knowing the current book production complicated for the readers. ${ }^{4}$ This had

4 There was no consensus around the negative impact of the growing number of books being published-an expert on readership, Jiří Trávníček, has repeatedly claimed that the country is over-filled with books and that readers are unable to make choices among such a wide range of books. Vladimír Pistorius, on the other hand, noted that 
a negative consequence in that new books quickly became old and their sale stagnated just a few weeks after they first came on the market. ${ }^{5}$

The number of registered publishing businesses has grown rapidly, too. In 2001, there were 3,136 (their number grew by 238 every year), however, only 1,196 of them were active (published at least one book in that year). By the year 2017, the number of registered publishers has grown to 6,986, with 2,151 active businesses; but only fewer than 100 published 30 or more books a year. Since 2001, the number of published books in the Czech Republic started rising sharply-the National Library recorded 14,321 in that year (and 12,557 of those were published for the first time), which was 2,356 more than in the previous year. Czech book production reached its peak in 2008, with 18,520 books published (and 16,386 of those published for the first time). Currently (in 2017), the number of published books per year stands at around 15,300. The proportion of fiction in the overall book production after 2000 is around $20 \%$, and its share has steadily declined-in the first half of the 1990s, fiction made up a third of the entire volume of published books. In 2001, there were 3,426 books of fiction published; its production reached its peak in 2016, when 5,559 books were published. There were 575 books of children's fiction published in 2001, and by 2016 their number increased to 2,157 .

It is likely that other Central European countries have experienced a similar boom. Jaroslav Šrank analysed Slovakian literary culture after 1989 and found that from 400 publishers in 1990, their number has grown to 1,155 in 2006 and went on increasing further year on year. In 2010, there were 1,500 registered publishing businesses in Slovakia. The trend in the published books in Slovakia has followed the Czech trend: in the second half of the 1990s, Slovakian publishers published around 4,500 books a year; in 2008, it was 9,171 and in 2014, 12,734 (see Šrank 2019: 59). Contrary to expectations, there was no significant share of e-books playing a part in the book market. They came on the Czech book market gradually, at the end of the 20oos, later than was the case in Western Europe and the USA.

the Czech book market is not unique in this respect in the international context and saw this trend of a larger book production as positive, stating that: "A larger number of published books only increases the supply. And which reader could possibly mind this?" (Trávníček, 2008: 42).

5 Jaroslav Císař interpreted the increase in published books as an attempt of the Czech publishers to capitalise on decreasing average expenses on publishing a book and holding their turn over at the same level. See Císař, https://tinyurl.com/y3q7zwcm. The current information on the Czech book market is found in a report by the Federation of Czech Booksellers and Publishers: https://tinyurl.com/yxgnrswy 
The democratic ethos which was brought by web 2.0 not only satisfied authoring but also publishing ambitions. Apart from the expansion in the number of publishers, the number of literary journals has also expanded. In 2000, several new periodicals appeared, which adopted only a digital format as a sufficient form of existence and no longer appeared in a printed format (the oldest Czech online literary journal Texty (Texts) has been published since 1995). In 2000, a monthly entitled Dobrá adresa started being published in a pdf format and every number looked like a base for a print journal; however, its full colour printed version would have been very expensive. The journal was comparable to printed literary periodicals, including the staffing of its editorial office (its staff included editors from established literary journals, such as Radim Kopáč, Vladimír Novotný, Kateřina Rudčenková and Jakub Šofar).

The iLiteratura.cz journal, which was also established in 2000, on the other hand, adopted a format of a webpage. The journal dropped the traditional periodicity principle and is constantly updated at article level. The journal focuses on reviewing current Czech and translated book production. Compared to the majority of Czech literary journals, iLiteratura monitors current literature in its broadest scope of covering language regions including marginal areas (such as Bosnian, Persian or Icelandic literature), and reviews even books which were not yet published in Czech translation.

Apart from professionally conceived and edited journals, there were a number of journals which were conceived on an amateur basis after 2000, established through enthusiasm and with lower ambitions than Dobrá adresa or iLiteratura, and number of them are no longer published now (these were e.g. Tramvaj načerno, Obštastník, Poetikon and Wagon). Some printed periodicals also followed the example of the online journals for financial reasons in that they moved purely online (e.g. Clinamen and Aluze). Some publishers have taken the opportunity of the relative ease and low cost of publishing online and have re-introduced several old journals, not published for many years (e.g. Divoké vino, re-introduced in 2002, and is one of the publishing platforms for authors compromised by their writing during the so-called normalisation period of the communist era).

\section{Reception}

The remediation process is manifested particularly strongly in reception. Initial concerns about the future of reading and traditional habits of book readers have not eventuated. Statistical research of readership in the Czech Republic (which is conducted by Jiří Trávníček since 2007) has shown that in the Czech literary 
culture (similar to other literary cultures), the Internet has not become the rival of reading that would take readers away from books and literature, but rather a supporter that opened up other spheres of reception where readers could share their opinions, suggestions and discussions, and made the distribution of literary texts easier. Czech research statistics (but also Polish) show that readers (who read at least one book a year) are also frequent Internet users, while non-readers spend less time reading books but also using the Internet (this varies according to age groups, for more detail see Trávníček 2011: 83). However, it cannot be argued that the arrival of the Internet has not impacted the reading culture and habits. Jiří Trávníček is of the view that the Internet has impacted readers' capabilities to absorb more extensive texts; however, he adds that this trend has not appeared with the Internet but the Internet has accelerated it. The interactive nature of the new medium was an aspect which impacted a change in reception more significantly. It made boundaries between roles (in behaviour) more relative in terms of reception-production and reception-mediation. Firstly, reception ceased to be "invisible" and started leaving more traces behind.

The reader takes on a greater and more active role thanks to the interactive nature of the digital media. The reader has the opportunity to directly comment on texts which s/he has just read (through comments via e.g. blogs where the literary text was published or they can choose some other place on the Internet). The reader can participate in collective production of a piece or can contribute to decisions made concerning its future development (e.g. online novels to be continued, such as Renčina červená knihovna (Renata's Chick-Flicks). In hypertexts, the reader shapes the text through selecting one of the given alternatives. The reader can also fairly easily strike a conversation with an author of a literary text.

However, remediation is not the only instigator of new developments in reception. The book market situation, its boom, has accelerated the developments in reception. Literary awards are an example of an institutionalised reception phenomenon of its kind, which apart from indicating prestige, also aids the reader's choice in an extensive range of new books on offer. The trend of an expansion within the literary system and of literary phenomena has affected even literary awards. In the 2000s, 74 literary awards (including prizes for literary competitions) were given out in the Czech Republic, 28 new awards were introduced and only two were abolished. ${ }^{6}$ Only some of these awards more

6 The data was drawn from the Literární ceny (Literary Awards) database maintained by the Institute of Czech Literature of the Czech Academy of Sciences (online: http:// 
substantially impacted the Czech literary culture. The impact can be "measured" by the professional kudos of the award, through its ability to capture the interest of the mass media and also promote current fiction to wide audiences. There were essentially two awards which had this potential: Státní cena za literaturu (The State Award for Literature) and Magnesia Litera.

The reception processes have not only undergone a quantitative but also a qualitative change. Compared to the last decade of the twentieth century, after 2000, the reception of Czech literature abroad has improved significantly. Literary festivals were a key medium, ${ }^{7}$ which played a significant part in this. The change in the way events organised by Martin Pluháček were arranged are an important example-in the 1990s, he organised closed meetings of poets at the Bítov castle, and in the new millennium he organised international festivals "Poetry without Borders." He no longer gathered poets at castles, making them more accessible to the general public in the university town of Olomouc. The first year was organised in October 2001, and apart from Czech poets, poets from France, Hungary, Germany, Poland, Portugal, Slovakia, Slovenia, the usA and Great Britain took part in the festival.

The Prague Writers' Festival has developed into an event of a European significance; its reputation was built on attendance of international authors awarded one of the prestigious literary awards (such as, Nadine Gordimer, Gao Xingjian, Margaret Atwood and William Styron). The literary festival Měsíc autorského čtení (The Month of Author Reading) has also grown into an event of international proportion-it was first organised by the Větrné mlýny publisher in Brno in 2000 and has gradually expanded into other cities (such as Košice, Ostrava, Wrocław and Lviv). Apart from the organising countries (Czech Republic, Slovakia and Poland), one of the world literatures takes part in the festival and has a status of a Czech guest (e.g. Canadian, French, Belarusian or Austrian).

The expansion of the reception horizon overseas has caused another wave of reception events. Some of the literary community compared the state and

www.ucl.cas.cz/ceny/). The increase in the number of literary awards is not an isolated phenomenon, it corresponds with a long-term international trend described by James F. English in his 2011 book entitled The Economy of Prestige: Prizes, Awards, and the Circulation of Cultural Value.

7 The Literary festival is a part of mediation; however, here the concern is not so much about its existence as a form of literary communication but more about the change in contextualising national literature (i.e. about the reception consequences of this form of mediation), which has not undergone a significant change (compared to other media). 
standard of current Czech and international literature and judged the Czech literary production as being in a critical and unsatisfactory state. This opinion started an extensive literary debate triggered by an article written by Štefan Švec "Krize české literatury" (Czech Literature in Crisis), published in March 2008 in the A2 journal. The main focus of this provocative article was the lack of interest in current Czech literary production among the general public. Drawing on current reader opinion polls, Švec argued that the Czech general public are relatively keen on reading and he saw the cause of the lack of interest in new Czech fiction itself. He stated that: "The only thing that the public do not read is current Czech "fine" fiction. And rightly so. It lives a life of its own, it is isolated from readers almost like literary science from literature. It is unable to bring in [current] topics" (Švec 2008: 1, 16-17). Švec's critique of current Czech literature is a comparison with other national literatures in which he values the quality of artistic rendition of current topics (including controversial ones, such as the Balkan war or disintegration the so-called western culture) and the ability to draw in readers. In line with the sub-title of his article "A Bit of Superficial Marketing Rubbish," he called for a much more active attempt to draw readers' attention and was ironic about those who claimed that literature can live in a voluntary ghetto and that books are published for the future or even for eternity.

Švec's provocative claims prompted many reactions and separated writers into two groups. One group was of the view that literature should react to current events in culture and the society and should seek suitable ways of presenting itself in the context of current society and media. Others, on the other hand, denied that there was a crisis and rejected the idea that they should consider the readers and select topics reflecting current events. Some literary critics accepted Švec's provocative claims as a challenge to return to the socio-critical role of literature, e.g. Jakub Vaníček in his essay "Krize? Kritika? Dějiny?" (Crisis? Critique? History?). The reception phenomenon of "crisis" has smoothly moved onto the next significant phenomenon of the end of 2010s-the articulation of requirements and expectations of the return to politically-engaged literature, particularly poetry. This has instigated another extensive debate in literary journals. The engaged literature in fact represented a particularly paradoxical form of a reception process, as there was not perception of present literary phenomena (as with the phenomenon of the "crisis") but the absence of literature associated with the current social and political context. Re-evaluation of deliberately being apolitical was an important part of the process which was adopted in the literary discourse immediately following the Velvet Revolution (these autonomist views were reflected in the views of the prose writer Jiří Kratochvil in the early 
1990 s who claimed that "nothing was further apart than politics and literature" (Kratochvil 1993: 1). The editor-in-chief of the literary journal Host, Miroslav Balaštík, referred to this view as an "aesthetics trap," which causes contempt for the reader and has, according to him, become the attitude of the current literary world: "By dropping the reflection of currency and being guarded by non-aesthetic functions, fiction lost many knowledgeable readers" (Kratochvil 1993: 1). The outlined reception process revealed also generational differences inside the literary scene and helped define the position of the young generation (particularly poets). The older generation who have gone through most of their literary careers in the communist era perceived the voices calling for new engagement as a danger of bringing in simplification and ideology into literature (e.g. Eva Kantůrková and Petr Král). The new generation of poets treated the topic of engagement without this historical baggage and viewed it in quite an open and broad sense, not just in terms of politics (e.g. Adam Borzič, a member of the Fantasía group of poets, defined engagement as a sensual captivation, harmony and compassion).

Czech literature was not the only one attempting to re-establish the connection between literature and politics. Similar tendencies can be observed in other Central European literatures and also elsewhere in the world. A similar debate went on in Poland in 2007 in the Tygodnik Powszechny journal, which was initiated by Igor Stokfiszewski in his article "Poezja a demokracja" (Poetry and Democracy); in Hungary there was a renewed interest in engaged literature when Viktor Orbán came to power in 2010, e.g. a popular anthology by Édes Hazám, Moje zlatá vlast (My golden country, 2012). Current information about sales of poetry growing year on year in Britain (which is apparently caused by an increasing interest in politics and poetry among the millennials; Ferguson 2019) illustrates the causal link between bringing politics into poetry, increase in readership and growing market success.

\section{Processing}

The last component of the Schmidt model of literary system is processing the phenomena regarded as literary. Its change caused by the remediation process in relation to the changes in reception was discussed earlier. In interactive media, it is hard to separate these changes from further processing of literary texts. ${ }^{8}$ These changes are clearly reflected in the state and forms of literary

8 This is not the only difference: the classical literary model was built on this and it started disappearing in the post-digital era. In fan fiction (i.e. an active engagement 
criticism, which was rated particularly badly after 2000 as part of occasional meta-critiques. The critical state of Czech literary criticism was caused not just by the media. One of the other causes was the blurring of the distinction between criticism and commercial promotion. A growing practice of recycling publishing advert annotations which, in some cases, appeared on review pages of Czech periodicals in only slightly adjusted form was regarded as a symptom of a crisis. It was felt that the key problem of current literary criticism was to be located in a staffing crisis. The texts by literary critics, who managed to build their reputation and respect in the previous decade (e.g. Martin C. Putna, Jan Lukeš or Pavel Janáček either reduced or stopped writing their literary critiques), formed only a small part of review sections.

The discontent with the state of Czech literary criticism culminated between the years 2008 and 2019. Many established literary critics and scientists (such as Petr A. Bílek, Ivo Harák and others) have expressed their opinions on this and it was on the agendas of literary institutions (e.g. the professional organisation, the Writers' Community organised a symposium focused on the topic). Further, there was a public dispute between the poet and critic Petr Král and the literary critic and theorist Jiři Trávníček; there was a clash of arguments between them: one endorsed the exclusive nature of literature and the other promoted openness of literature to the readers. Even the alleged "tasking" of authors by literary criticism was discussed publicly. ${ }^{9}$

The role of literary criticism and its prestige changed through the media of communication. Together with the evolution of the Internet from an expert to a social medium, where the content is largely developed by its users, the communication base of new literature was also changing. Alongside printed and online literary periodicals, an ever wider public space for informing readers and lay reviews was opening. At the turn of the investigated period, literary-focused websites built on a social network principle (e.g. BookFan.eu where literary criticism is fully replaced by reader recommendations based on personal preferences) are not an exception. The space for reader reviews was not just provided by specialised thematic social networks but also by online publishers

of readers in a popular narrative), even the distinction between production and processing is challenged. This adaptation form of processing has developed in Czech literature (similarly to other literatures) particularly thanks to open publishing platforms on the Internet where communities of readers can share their processing and elaborate well-known stories (e.g. Harry Potter).

9 For example, Petr Král’s "Mluvíme o tomtéž?" (Are We Talking About the Same Thing?). 
(e.g. bux.cz, http://knihy.vltava.cz, http://knihy.abz.cz), and also numerous apps and community websites via the global social network Facebook, e.g. Co čteme group (What We Read) started being used for mutual book recommendations. It became difficult to distinguish between a critical reflection on current literature and a virtual advert, and it can be even argued that a new (virtual) form of literary criticism was established.

In 2010s, virtual criticism was introduced even into the audiovisual content of social media-similarly to other national cultures, a fast expanding community of booktubers (i.e. readers who publish their reflections on their reading experiences particularly on youtube) started getting involved in reflecting on the current book production also in the Czech literary culture. Gradually, a particular genre structure of these literary meta-texts is developed: such as, Book Haul (videos informing about a purchased or otherwise acquired book), Wrap Up (videos about books a booktuber has just read) or $\mathrm{TBR} /$ to be read (videos about books a booktuber is planning to read). A discussion usually develops among members of these communities where tagging or inviting particular subscribers to join discussions. Similar to other areas of youtubering, here amateur authors of video-content are interconnected with commercial subjects operating in the particular section of the market. Booktuber contributions are not only products of passionate readership but tend to also be a part of an advertising campaign. This commercial aspect of booktuber contributions may remain hidden but often is revealed, e.g. through the video being made specifically for a publisher's channel. The connection between a critical reflection on a literary piece with its commercial presence, which was often rejected by the Czech press in the 2000 , is established as a legitimate approach, even a principle. The traditional literary criticism is pushed aside to the position of an intellectually demanding, hard to understand and an elitist reflection on current literature. The number views of the most successful Czech booktubers range in many thousands (e.g. the author of the Radši knihu (Prefer a Book) channel has regularly three to five thousand viewings of her videos). The traditional literary reviews published in literary journals, which have the circulation of a maximum of 1,000, can never achieve such an impact. And the impact, or its commodification, is the key feature of the new forms of processing of literary phenomena.

Among the actors of literary communication, new actors who are referred to as "book influences" (booktubers belong to this group too but it also covers literary-engaged users of other media) appeared with the social media boom. The book influencer, Lucie Zelinková, is a good example of interconnecting meta-literary activities with commercial interests. This influencer publishes 
reader posts on the Instagram (https://www.instagram.com/luciezel/), and currently has 73,200 followers. She is also a product manager of one the large online book stores, Martinus.cz. What seems to be an authentic and subjective expression of a reader's interest equally represents a commercial interest of an institutional actor on the book market, which is mediated by an influential user of social network.

\section{Conclusion}

The research described in this paper has shown that Czech literary culture after 2000 has gone through changes which have affected all areas (or roles of action) forming the traditional model of literary system proposed by Siegfried J. Schmidt. Remediation appears the strongest instigator of these changes, one that has brought a range of new literary phenomena and has accelerated more substantive changes in literary discourse. In production, it brought new literary techniques requiring the interactive and algorithmic features of digital media and particularly expanding the publishing space and democratisation of the access to it. This caused an increase in literary production among the general public and also an increase in the number of texts available in the public space. A similar trend soon affected processing, particularly through the expansion of the book market and an increase in the numbers of literary periodicals available. A crisis in reception followed, as the book market boom found an extension in a growing number of public and formative reception acts (e.g. number of literary awards) and their partial devaluation. A qualitative change in reception towards internationalisation has further exacerbated this critical situation, as it caused scepticism concerning the current state of Czech literature and its current social role and prestige among a section of literary public. A partial solution to this situation was, similarly to other European countries, sought in the renewal or strengthening of the role of social criticism and engagement of literature. The systemic change in processing literary phenomena was most clearly reflected in the change in the literary criticism discourse. Even here the main object of changes-the process of remediation-was reflected in the redistribution of roles between individual and institutional actors of literary communication. Review sections of literary journals and opinions of literary critics have started competing with new forms of reflection on current literature, which started happening horizontally among individual readers and within their communities, thanks to the architecture of social networks. Literary criticism distributed via print media could not compete with content spread virtually (supported by commercial institutional actors) in terms of its reach and impact. On the one 
hand, the role of institutions in literary communication (e.g. publishers and criticism) weakened, on the other hand, some institutions have returned through the back door and joined in forming ideas about literature/literary image represented by individual amateur actors in the literary process.

Given that the process of remediation is transnational in nature, the mentioned processes in Czech literary culture happened in parallel with other Central European and other literatures. In the Czech context, the tendency to domesticate literary communication was stronger than in the neighbouring literatures-even elite (e.g. experimental) ways of using digital media were introduced. It can certainly be argued that the evolutionary change in the literary system, which is happening in the post-digital era, is so extensive that the model of literary system formed in the pre-digital era is becoming inadequate for describing particular aspects. The distribution of the roles of action is much more complex in the current times; these roles intersect and the boundaries between them are frequently blurred.

Translated by Melvyn Clarke

\section{| References}

Bílek, Patr. A. "Udělej si sám. O sebeukájení dnešních literárních kritiků” (Do it yourself: on self-gratification of current literary critics) A2 5 (2008): 7.

Císař, Jaroslav. “Základní fakta o knižní produkci čr v roce 2001." (Key facts on the book production in the Czech republic in 2001), 2019, http://www.sckn. cz/index.php? $\mathrm{p}=$ fakta2001. Accessed 10 April 2019.

Cramer, Florian. "What is 'Post-digital'?" APRJA 3.1 (2014), http://www.aprja. net $/ \mathrm{p}=1318$. Accessed 10 April 2019.

Hodrová Daniela, Stránský Jiří, Vajchr Marek, Neff Ondřej, Štampach, Odilo Ivan, Dvořák Joachim, Pavelka Zdenko. "Dvě otázky." (Two questions). Literární noviny 12.39 (2001): 10.

Ferguson, Donna "Poetry Sales Soar as Political Millennials Search for Clarity," https://tinyurl.com/y8ongd39. Accessed 21 Jan. 2019.

Harák, Ivo. "Fikční světy kritiky aneb ..." (Fictional world of criticism ...). Dokořán 13.51 (2009): 40-46.

Košinská, Eva. Čtenáři v internetových komunitách (zaměřených na literaturu). (Readers in Internet communities (focused on literature)), diplomová práce (MA Thesis). Praha: Univerzita Karlova v Praze, Filozofická fakulta, 2009. 
Král, Jiř́i T. “Kopání do mrtvoly.” (Kicking a corpse). A2 13 (2008): 8.

Kratochvil, Jiří. "Česká literatura a politik." (Czech literature and politics). Tvar, 4: 27/28 (1993): 1.

Křivánek, Vladimír. "Hradecké sympozium o kritice." (Hradec symposium on criticism). Dokořán 13.51 (2009): 38-40.

Král, Petr. "Mluvíme o tomtéž?" (Are we talking about the same thing?).

Tvar 19.10 (2009): 6-7.

Materna, Jiří. Poezie umélého světa. (Poetry of an artificial world). Brno: Backstage Books, 2016.

Povídky Ze Zdi (Společné Tvưrčí Psaní) (Short Stories from the Wall (Community Creative Writing), https://tinyurl.com/yahy4wgg. Accessed 10 April 2019.

Př́běhy Na Padesát Slov. (Stories of Fifty Words), http://pribehynapadesatslov.cz. Accessed 10 April 2019.

Renčina Červená Knihovna. (Renata’s Chick Flicks), http://www.cervenaknihovna.com/. Accessed 10 April 2019.

Růžička, Jiří G. "Anarchie v nakladatelském průmyslu." (Anarchy in the Publishing Industry). A2 26 (2008), https://tinyurl.com/y8d80xoj. Accessed 10 April 2019.

Schmidt, Siegfried J. Přesahování literatury (Crossovers of Literature). Trans. Zuzana Adamová. Praha: ÚčL AV ČR, 2008.

Slovensko Píše Román. (Slovakia is Writing a Novel), http://slovenskopiseroman.sk. Accessed 10 April 2019.

Šrank, Jaroslav. Aktéri a tendencie literárnej kultúry na Slovensku po roku 1989. (The Actors and Trends in Slovakian Literary Culture after 1989). Bratislava: Univerzita Komenského, 2019.

Švec, Štefan P. B. "Krize české literatury. Pár povrchních marketingových kecü“ (Czech Literature in Crisis: A Bit of Superficial Marketing Rubbish). A2 4.13 (2008): 1, 16-17.

Trávníček, Jiří. "Nakladatelé a knihkupci jsou velmi žárliví na poskytování informací. Rozhovor s Vladimírem Pistoriem o tom, jak funguje knižní trh." (Publishers and Booksellers are Jealous about Giving out Information, Interview with Vladimír Pistorius about How the Book Market Operates). Host 7 (2008): 41-46.

Trávníček, Jiří. Čtenáři a internauti. Obyvatelé České republiky a jejich vztah ke čtení. (Readers and Internauts: Czech Population and their Attitudes to Reading). Brno: Host, 2011.

Viewegh, Michal. Blogový román (Blog Novel), http://blogovyroman.idnes.cz. Accessed 10 April 2019. 


\section{| Abstrakt \\ Karel Piorecký, Vojtěch Malínek \\ Czeska kultura literacka w erze (post)cyfrowej}

Studium poświęcone jest zmianom następującym w czeskiej kulturze literackiej po 2000 r. i związanym z rozwojem mediów internetowych. Metodologiczny punkt wyjścia stanowi analiza modelu systemu literackiego o strukturze zaproponowanej przez Siegfrieda J. Schmidta. Zwrócono uwagę na nowe metody twórcze, posługujące się specyficznymi możliwościami interaktywnych mediów sieciowych, oraz wpływ publicznie dostępnych portali wydawniczych na wzrost aktywności literackiej części populacji. W tekście analizowane są zarówno możliwości publikacji w sieci internetowej, wykorzystywane głównie przez pisarzy amatorów, jak również komplementarne zjawiska występujące w produkcji drukowanej oraz wpływ innowacji na dynamikę rynku książki. Procesy recepcji rozpatrywane są przede wszystkim w związku ze wzrostem znaczenia roli czytelnika w mediach interaktywnych, a szczególną uwagę poświęca się jakościowej zmianie ram recepcji (ponadnarodowa i pozaliteracka kontekstualizacja). Podejście do zjawisk literackich jest w dużej mierze związane z refleksją nad złym stanem współczesnej krytyki literackiej i nowych, wirtualnych form oceniania literatury. Artykuł zawiera konkluzję, że zmiana ewolucyjna, którą ze sobą niesie rozpowszechnienie się mediów cyfrowych w komunikacji literackiej, była tak zasadnicza, iż Schmidtowski model systemu literackiego okazał się niewystarczający do jej opisu.

Słowa kluczowe: kultura literacka; system literacki; rynek książki; media cyfrowe; Internet; sieci społecznościowe

\section{| Abstract}

KAREl Piorecký, VoJTĚCH MALÍnEK

Czech Literary Culture in the Post-Digital Era

This study examines the changes within Czech literary culture since 2000 in relation to the process of remediation. The starting methodological point is in examining a structure of a literary system within a model proposed by Siegfried J. Schmidt. The impact of new creative approaches which utilise interactive network media and also of available publishing platforms are observed in terms of the increase in the size of the literary active group of the population. The study further investigates publishing options via the Internet used mainly by amateur authors, complementary 
phenomena in print production, as well as the impact of these innovative forms on the dynamics of the book market. The ways in which texts are received are examined particularly from the point of enhancing the role of the reader within interactive media and attention is paid to the qualitative changes within the reception frameworks (transnational and non-literary contexts). And finally, the ways in which literary phenomena are handled is largely related to the reflection of the critical state of the current literary criticism and new virtual formats of critiquing literature. The study shows that the evolutionary changes which were brought about by extending the use of digital media within literary communication have been so extensive that the Schmidt model of analysis has proven insufficient.

Keywords: literary culture; literary system; book market; digital media; the Internet; social networks

\section{| About the Authors}

Karel Piorecký, PhD has graduated in Czech and German (Faculty of Education, Charles University, Prague), and undertaken postgraduate studies in Modern Czech Literature at Faculty of Arts at University of South Bohemia in České Budějovice (Cyech Republic). He currently conducts research at the Institute of Czech Literature of the Czech Academy of Sciences, Department of Research on the 2oth Century and Contemporary Literature. His focus is particularly on the history of modern Czech poetry and connection between literature and new media. He published a monograph entitled Česká poezie v postmoderní situaci (Czech Poetry in a Postmodern Situation) (2011) and Česká literatura a nová média (Czech Literature and New Media) (2016). E-mail: piorecky@ucl.cas.cz

Vojtěch Malínek, PhD specialises in Czech Literature and Literary Theory and conducts research at the Institute of Czech Literature of the Czech Academy of Sciences. $\mathrm{He}$ is the coordinator of Czech Literary Bibliography Research Infrastructure and co-chair of Bibliographical Data Working Group within the DARIAH-ERIC Consortium. His areas of research include: literary bibliographies, data analysis and digital humanities. He is the chief investigator on several infrastructure research projects such as: Digitising of Retrospective Bibliography of Czech Literature 1770-1945 (2009-2011), Czech Literary Bibliography 1945-1960 (2012-2015), Czech Literary Bibliography Research Infrastructure I (2016-2019), Czech Literary Internet (2017-2021) and Czech Literary Bibliography Research Infrastructure II (2020-2022). E-mail:malinek@ucl.cas.cz 